\title{
THE CONCEPT AND CONTENT OF THE CONSTITUTIONAL PRINCIPLE OF JUSTICE
}

\author{
Nataliya Shelever, \\ Associate Professor of the Department of Administrative, \\ Financial and Informative Law, \\ Uzhgorod National University \\ $\mathrm{PhD}$ in Law, Associate Professor \\ https://orcid.org/0000-0003-3641-4910 \\ Researcher ID: AAI-9623-2021 \\ (https://publons.com/researcher/4326660/nataliya-shelever/) \\ nataliya.shelever@uzhnu.edu.ua
}

\section{Summary}

The purpose of the article is to study the concept and content of the constitutional principle of justice, its impact on constitutional relations, identifying problems that arose during the implementation of this principle during quarantine restrictions due to the pandemic of COVID-19.

This goal was achieved through the use of such methods as analysis of comparative law and formal law method.

The study found that the principle of justice, although not enshrined in the Basic Law of Ukraine, but it goes through the Constitution of Ukraine and procedural codes. The problematic issue is that there is no legislative definition of «justice». The practice of the Constitutional Court of Ukraine on the application of the principle of justice in its decisions is analyzed. It is substantiated that justice is a concept much broader than law and is a criterion for the legitimation of state power.

The problems of realization of the constitutional principle of justice are investigated. It was found that the principles of law, which are enshrined in the Constitution of Ukraine and current legislation of Ukraine, are not properly implemented in our country. The reason for this is the mentality of Ukrainians, which is characterized by low legal and political culture, violation of the law, distrust to the authorities, devaluation of moral and spiritual values. On the part of officials, it is a misuse of office positions.

It is justified that justice requires equal application of the law for all. However, everyone has his/ her own understanding and vision of justice. This led to problems during the coronavirus pandemic. Violations such as the violation of the constitutional right to education have been identified, namely distance learning leads to a violation of the principles of justice and equality. Restrictions on small and medium-sized businesses during the COVID-19 pandemic discriminated against entrepreneurs compared to large businesses.

As a result of the study, it was concluded that justice is a legal value and a fundamental principle of law, which permeates both the Constitution of Ukraine and current legislation. The realization of justice can be done only by observing the law. In Ukraine, it is quite difficult to implement this principle, because the laws are often unfair. During the quarantine restrictions, violations of constitutional human rights were revealed. Overcoming corruption and raising the legal culture and legal awareness of Ukrainians should be a necessary step for the effective implementation of the principle of justice.

Key words: justice, the Constitutional Court of Ukraine, law, legal value, principle of law, pandemic COVID-19, Constitution of Ukraine. 


\section{Introduction}

The principle of justice is a fundamental principle in the constitutional law of Ukraine, which permeates all spheres of public life. In connection with Ukraine's desire to become a full member of the EU and NATO, the study of the essence of this fundamental principle is a topical issue today. The above topics have been studied by many constitutional scholars, such as O. Golovchenko, M. Kozyubra, A. Petryshyn, S. Pogrebnyak, P. Rabinovych, M. Savchyn, Y. Todyka and others. However, in our opinion, this issue is not sufficiently studied in view of the pandemic of the coronavirus COVID-19, which has made its adjustments. It has affected the lives of the whole world, which has changed significantly during the pandemic. Therefore, the study of problematic issues of the implementation of the constitutional principle of justice during the COVID-19 pandemic is an important issue of today.

The purpose of the article is to study the essence, content of the constitutional principle of justice, its impact on public relations. We set ourselves the following research tasks: to find out the place and significance of the constitutional principle of justice in the legal system, its essence and impact on law, to identify problematic issues of its implementation during quarantine restrictions and to indicate effective ways to overcome them. Our methods include description, comparison, analysis, synthesis, system-structural method, formal-legal method, which gave us the opportunity to solve our problems.

Thus, the methods of formal logic: description, comparison, analysis, synthesis were used by the author to characterize the normative content of the constitutional principle of justice. Due to the system-structural method, we have considered the regulatory significance of the constitutional principle of justice. The formal-legal method made it possible to investigate the problems of implementation of this principle during the COVID-19 pandemic.

\section{The essence of the constitutional prin- ciple of justice}

Constitutional law occupies a special place in the entire legal system. V. Chervonyuk notes: "Obviously, this branch of law cannot be recog- nized as a single-ordered opposed to other profile branches - it is a fundamental basic branch of law that reflects the general legal regimes, legal means and methods of regulation, which are specifically embodied in other branches of law, including those related to the relevant branches of law» (Chervonyuk, 2004). G. Komkova believes that constitutional law itself has such global categories, "which are important ideological attitudes for all other branches of law» (Komkova, 2008, p. 26).

The Constitution is not only the basic legal act in the country, but it plays a more important role, because it is the constitution that enshrines the basic legal principles that are fundamental to the entire legal system of the country (Kravets, 2005).

The category of law is being looked upon in law as the principle of law (Yavich, 1989, p. 150) and as the "quality of law» (Baranov, 2003, p. 312-313).

Considering the relationship between justice and law, L. Yavich noted that we can talk about the relationship within the two planes. Thus, he writes that on the one hand «it is a question of assessing the law in terms of the economic, political and other factual relations he protects... In the second aspect, the problem of law and justice is more specific, it foresees the understanding of justice not as an outside towards the legal activity factor, but as a special legal principle of law, which expresses some properties, aspects of the legal form» (Yavich, 1976, p. 156).

G. Maltsev believes that «the relationship between law and justice is based on the fact that the legal relationship can always be interpreted as a special type of distributive relationships. The object of division here are the rights and responsibilities of the participants of mutual social communication» (Maltsev, 1977, p. 14). «Justice means accepted by society as a morally justified and correct scale for comparing the actions of the subject for the benefit (or harm) of society and others with the corresponding actions of the latter" (Maltsev, 1977, p. 54). A. Ekimov understands justice as a «morally justified criterion for comparing the actions of subjects, in accordance with which everyone is paid off for his actions in the form of certain consequences» (Ekimov, 1980). 
According to G. Maltsev, "the connection between law and justice is based on the fact that legal relations can always be interpreted as a special type of distributive relations. The object of division here are the rights and responsibilities of participants in mutual social communication» (Maltsev, 1977, p. 143).

Z. Berbeshkina believes that justice is «a concept of moral consciousness, which characterizes the legitimacy of assessment of economic, social, legal phenomena of reality and actions of people...» (Berbeshkina, 1983, p. 147).

M. Rutkevich notes that «the concept of justice fixes the moral and legal idea of what corresponds and does not correspond to laws, norms of law and social, prevailing in society morality...» (Rutkevich, 1986, p. 148).

It should be noted that there is no direct norm in the Constitution of Ukraine that enshrines the principle of justice. However, some constitutional requirements follow from this principle and this indicates its indirect consolidation. According to S. Pogrebnyak, «for example, the idea of justice is concretized in the principle of non bis in idem, enshrined in Art. 61 of the Constitution of Ukraine. The principle of justice also stipulates the obligation to promulgate regulations (Part 3 of Article 57 of the Constitution), the general prohibition of retroactive laws (Part 1 of Article 58 of the Constitution), the right not to be forced to testify against oneself (Part 1 of Article 63 of the Constitution), the right to judicial protection (Article 55 of the Constitution), etc.» (Pohrebniak, 2009, p. 31-32).

From the standpoint of constitutional axiology, justice is a controversial category. This is a legal value that is considered simultaneously with such values as freedom, humanism, the rule of law, equality, and so on. Justice is a measure of equality and freedom, so it is often associated with equality and freedom.

E. Renyov notes: «Consolidating the instrumental set of means for resolving social contradictions, the Constitution of Ukraine simultaneously acts as an axiological basis for removing social contradictions, which is reflected in the practical and applied activities of public authorities through the criteria of constitutionality of their decisions. A special place in the system of constitutional criteria for resolving social contradictions belongs to the requirements of justice.
The requirement of justice possesses, according to the content of the Constitution of Ukraine, a multifaceted, universal content, which has different legal forms of its manifestation. It acts as an institution of the legal status of man and citizen, and as a principle of the rule of law, and moreover, as a political and legal basis of civil society, a special form of achieving legal balance based on the balance of interests of different social groups» (Renyov, 2016, p. 93).

Justice is a constitutional principle of justice. Thus, in the decision of the Constitutional Court of Ukraine of January 30, 2003 №3-rp/2003 (Rishennia Konstytutsiinoho Sudu Ukrainy, 2003) in the case of consideration by the court of certain rulings of the investigator and prosecutor it is noted that «justice is defined as such only that it meets the requirements of justice and ensures effective restoration of rights».

S. Alekseev notes: "Justice in its essence as a socio-moral phenomenon in our society - in its specifically class, socialist expression, it acquires the meaning of the legal principle to the extent that it is embodied in the normative-legal way of regulation, in those principles «proportionality», «equal scale», etc., which are inherent in the very construction of legal instruments. Justice has an independent meaning in legal practice: it is one of the leading principles in resolving legal cases, when the court or other competent authorities are given "discretion», i.e. when they perform a function of individual regulation (for example, in determining the amount of alimony paid on maintenance of parents, when establishing the exact measure of punishment, etc.». (Alekseev, 1972, p.108-109).

Justice is essentially broader than law. The specificity of justice in normativeness, because if a just idea receives normative consolidation, it changes to law, that is, it becomes law. Law is normatively enshrined justice (Kuravshivili, 1988).

Justice is a criterion for legitimizing of state power. In constitutional and legal relations, this principle is embodied by providing access to positions of civil servants. V. Vasylchuk believes that the "reflection of the principle of "everyone» in the activities of state bodies is the distribution of competence between different branches of government, as well as the definition of the limits of authority and scope of each 
of them. Observance by authorized entities in their professional activity of the requirement of proportionality, prohibition of exceeding the necessary measure, requirement of equal treatment and prohibition of abuse of rights ensures the exercise of state power on the basis of justice» (Vasylchuk, 2013).

\section{Implementation of the principle of jus- tice in constitutional and legal relations}

The principles of law are enshrined both in the current legislation of Ukraine and in the Constitution of Ukraine. However, the requirements that enshrine these principles are not being implemented properly. This is due to the mentality of Ukrainians. Disadvantages include low culture, non-compliance with the law, devaluation of spiritual and moral values, distrust of government, and so on.

In our opinion, a necessary factor in the realization of justice is a person's awareness of this justice, its value in society, the benefits that people will receive if justice is realized in practice and the state is ruled by a just law. This is what our state is striving for at the moment. A democratic state always tries to instill in its citizens the observance of such a value as justice. However, it also depends on the personal data of citizens, the level of their legal culture, legal awareness, etc.

We fully agree with the opinion of S. Suniegin that «one of the most important reasons for such a crisis of consciousness of many Ukrainians, in our opinion, is the subjects of law ignoring the objective moral content of these principles or distorted and one-sided perception of basic moral postulates, based, as a rule, on a purely selfish way of thinking. Thus, the problem of correct understanding of the essence of the moral content of justice, freedom, equality and humanism as fundamental principles of law becomes especially relevant in today's conditions» (Suniehin, 2012, p. 275).

We fully agree with the opinion of S. Suniegin that:

«1) firstly, the fundamental principles of law are manifested primarily in their moral content, which has an objective basis that should correct the subjective perception of their content. One-sided, distorted subjective perception and understanding of the ideas of justice, equal- ity, freedom and humanism, as a rule, is based on the selfish desire to satisfy only the personal (private) interests of a person;

2) secondly, positive law must take into account and enshrine these fundamental principles, based on the content of their objective moral dimension, consistent with the fundamental laws of natural human coexistence;

3) thirdly, the fundamental principles of law will only have a high positive effect in their implementation in the relevant legal, law enforcement activities and legal relations, when they are filled with traditional moral content, i.e. will be consistent with the requirements and principles of prevailing morality in society. It is the moral dimension of the fundamental principles of law that ensures their proper implementation, and directs the use, implementation, observance and application of legal requirements to achieve the public good, rather than private and often immoral interests of the individual or persons who, in our opinion, lie in based on their distorted subjective perception and understanding» (Suniehin, 2012, p. 278).

Justice embodied in the rule of law requires that the law was applied equally to all. However, we should not forget that the law can not take into account all the diversity of social relations. Therefore, in the decision-making process, officials should be guided by the letter of the law, and their idea of justice, and which of these decisions will be the most correct.

The problem in practice is that everyone understands and perceives justice in their own way. What is right for one is unfair for another. For example, in the context of quarantine restrictions, it is advisable to consider such an issue as distance learning. Yes, on the one hand, it provided an opportunity, though not fully, but to teach students. On the other hand, low-income families are unable to provide their children with gadgets and computers. In addition, there is no Internet in remote mountain villages. In this case, is it not a violation of the constitutional right to education? In our opinion, the state should take this problem into account and take measures to overcome it. The consequence of the pandemic is an economic crisis and growing inequality in society.

It was a violation of the constitutional right to work that during the pandemic, large shop- 
ping centers operated and small shops were closed for quarantine. We believe that this approach was a violation of the principle of justice, and the state needs to reduce tax and administrative pressure on small and medium-sized businesses.

The principle of justice implies a system that cannot be violated, because it will lead to negative consequences. Systematic means the simultaneous realization of the values of the principle of justice in the legislative, law enforcement spheres. It is interesting that the principle of justice is enshrined in law. However, if the rule of law does not comply with this principle, the legislator is not obliged to change or repeal it. Therefore, in practice, very often unfair rules of law can be implemented, which leads to violations of human and civil rights.

It is important to study the implementation of the principle of justice in law enforcement, because life is changing, judicial practice is evolving and many issues are currently unexplored. At present, we are witnessing what unfair laws are often passed by the Verkhovna Rada of Ukraine. An unjust law is not accepted by society and is not a right. It is impossible to build a state governed by the rule of law without just laws. Unfair court decisions are also not perceived as justice. They undermine the authority of the judiciary and are not justice.It is on the basis of the analysis of court decisions that society has an idea of whether there is justice in the state. It is thanks to fair court decisions that the rights of citizens are protected.

So, if the laws are fair, then the law enforcement acts are also fair. If the laws are unfair, the law enforcement acts are unfair. This quite logically follows from the interrelation of laws and law enforcement acts. Justice and legality are different concepts. Sometimes we witness legitimate but not fair decisions. And this is a big problem.

If law enforcement acts are fair, then the authority of law and trust in government by society increases. Such an act will be carried out because it finds the moral approval of all members of society, as opposed to the unjust. Therefore, the issue of justice in the practice of government should be the number one issue in a democracy.
O. Vlasova rightly states: «The principle of justice, arising in the ethical and moral environment, imposes on the subjects of the law enforcement process (judges, lawyers, plaintiffs, defendants, accused, victims, etc.) the requirement to comply with ethics and morality. Any manifestations of humiliation of human dignity committed by the participants in law enforcement cause great harm and undermine the just beginning of the law enforcement process. Justice is based on the "golden" rule of morality: «do not do to others what you do not wish for yourself" and is a vocation of equality of all members of this society in their dignity and rights. Justice as a spiritual and moral principle contains in its content the ability of each person to feel a sense of self-worth.The main thing that the principle of justice requires is respect for the rights and dignity of the people» (Vlasova, 2008, p. 23).

The problem of justice has always aroused interest in society and scientists. Therefore, clarifying the essence of justice in law is an urgent issue today. It's because the activity of all branches of government in Ukraine is reduced to the application of the principle of justice in practice. Justice is aimed at satisfying not only certain segments of the population, but also the interests of society as a whole.

\section{Conclusions}

Therefore, based on the above, we come to the following conclusions. Justice is a fundamental legal value. This is a legal principle that permeates all areas of law. Although there is no direct enshrinement in the Constitution of Ukraine, its influence can be traced in the procedural codes, in fact in the Constitution itself. As a legal value, justice can only be achieved and ensured by complying with the law. However, the problem in Ukraine is that the laws themselves are often unfair. Justice is a criterion of the legitimacy of the law. Another problem is that the Ukrainian mentality is quite specific. The result is a violation of constitutional human rights during the COVID-19 pandemic. Therefore, it is quite difficult to implement the constitutional principle of justice in life. After all, this is opposed, first of all, by corruption, low legal culture and consciousness of Ukrainians, as well as abuse of office by officials. 


\section{Bibliography:}

1. Алексеев, С. С. (1972). Проблемы теории права. Курс лекций в двух томах. T.І. Основные вопросы общей теории социалистического права. Свердловск, 396 с.

2. Баранов, В. М. (1989). Истинность норм советского права. Проблемы теории и практики. Саратов: Издво Сарат. ун-та, 400 с.

3. Бербешкина, 3. А. (1983). Справедливость как социально-философская категория. Москва: Мысль, 209 с.

4. Васильчук, В. О. (2013). Справедливість як категорія права (автореф. дис. ... канд. юр. наук: 12.00.12). Львів, 23 с.

5. Власова, О. В. (2008). Справедливость, равенство и достоинство личности в праве. Вестник Югорского государственного университета, Выпуск 7(8), С. 22-24.

6. Комкова, Г. Н. (2008). Категория «конституционные принципы» в современной науке конституционного права. Конституционные чтения: межвузов. сб. науч. трудов. Саратов: Поволжская академия государственной службы им. П.А. Столыпина, Вып. 9.

7. Кравец, И. А. (2005). Российский конституционализм: проблемы становления, развития и осуществления. Монография. СПб.: Юридический центр-Пресс, 910 с.

8. Куравшивили, Б. П. (1988). «Секретарь и председатель в одном лице». Известия.

9. Мальцев, Г. В. (1977). Социальная справедливость и право. Москва: Издательство: Мысль, 255 с.

10. Погребняк, С. (2009). Закріплення основоположних принципів права в Конституції України. Вісник Академії правових наук України, 4 (59), С. 31-39.

11. Ренёв, Е. В. (2016). Справедливость как базовая конституционная ценность. Legea si viata, 6/2 (294), С. 91-94.

12. Рішення Конституційного Суду України у справі за конституційним поданням Верховного Суду України щодо відповідності Конституції України (конституційності) положень частини третьої статті 120, частини шостої статті 234, частини третьої статті 236 Кримінально-процесуального кодексу України (справа про розгляд судом окремих постанов слідчого і прокурора) (2003), № 3-pп/2003. URL: https:// ccu.gov.ua/docs/470

13. Руткевич, М. Н. (1986). Социалистическая справедливость. Социологические исследования, 3, С. 15-23.

14. Сунєгін, С. О. (2012). Основоположні принципи права: загальна характеристика та деякі аспекти реалізації. Альманах права, 3, С. 275-279.

15. Червонюк, В. И. (2004). Контитуционное право России. Москва: Термика, Инфра-М, 432 с.

16. Экимов, А. И. (1980). Справедливость и социалистическое право. Ленинград: Изд-во Ленингр. ун-та, 120 с.
17. Явич, Л. С. (1976). Общая теория права. Ленинград: Издво Ленинград. ун-та, 288 с.

\section{References:}

1. Alekseev, S. S. (1972). Problemy teorii prava. Kurs lektsiy $v$ dvukh tomakh. T.l. Osnovnye voprosy obshchey teorii sotsialisticheskogo prava. [Problems of the theory of law]. Sverdlovsk. [in Russian].

2. Baranov, V. M. (1989). Istinnost norm sovetskogo prava. Problemy teorii i praktiki [The truth of the rules of Soviet law. Problems of theory and practice]. Saratov: Izd-vo Sarat. un-ta. [in Russian].

3. Berbeshkina, Z. A. (1983). Spravedlivost kak sotsialnofilosofskaya kategoriya. [Justice as a socio-philosophical category]. Moscow: Mysl. [in Russian].

4. Vasylchuk, V. O. (2013). Spravedlyvist yak katehoriia prava [Justice as a category of law] (Extended abstract of Candidat's thesis). Lviv. [in Ukrainian].

5. Vlasova, O.V. (2008). Spravedlivost, ravenstvo i dostoinstvo lichnosti $v$ prave [Justice, equality and dignity of the individual in law]. Vestnik Yugorskogo gosudarstvennogo universiteta, 7 (8), 22-24. [in Russian].

6. Komkova, G. N. (2008). Kategoriya «konstitutsionnye printsipy» $\vee$ sovremennoy nauke konstitutsionnogo prava [The category of «constitutional principles» in the modern science of constitutional law]. Konstitutsionnye chteniya. Saratov: Povolzhskaya akademiya gosudarstvennoy sluzhby im. P.A. Stolypina. [in Russian].

7. Kravets, I. A. (2005). Rossiyskiy konstitutsionalizm: problemy stanovleniya, razvitiya i osushchestvleniya [Russian constitutionalism: problems of formation, development and implementation]. SPb.: Yuridicheskiy tsentr-Press. [in Russian].

8. Kuravshivili, B. P. (1988). Sekretar i predsedatel v odnom litse [Secretary and Chairman in one person]. Izvestiya. [in Russian].

9. Maltsev, G. V. (1977). Sotsialnaya spravedlivost i pravo. [Social justice and law]. Moscow: Izdatelstvo: Mysl. [in Russian].

10. Pohrebniak, S. (2009). Zakriplennia osnovopolozhnykh pryntsypiv prava v Konstytutsii Ukrainy. [Consolidation of fundamental principles of law in the Constitution of Ukraine]. Visnyk Akademii pravovykh nauk Ukrainy, 4 (59), 31-39. [ in Ukrainian].

11. Renev, Ye. V. (2016). Spravedlivost kak bazovaya konstitutsionnaya tsennost [Justice as a basic constitutional value]. Legea si viata, 6/2 (294), 91-94. [in Russian].

12. Rishennia Konstytutsiinoho Sudu Ukrainy [Decision of the Constitutional Court of Ukraine] (2003), 3-rp/2003. Available from: https://ccu.gov.ua/docs/470 
13. Rutkevich, M.N. (1986). Sotsialisticheskaya spravedlivost. [Socialist justice]. Sotsiologicheskie issledovaniya, 3, 1523. [in Russian].

14. Suniehin, S. O. (2012). Osnovopolozhni pryntsypy prava: zahalna kharakterystyka ta deiaki aspekty realizatsii [Fundamental principles of law: general characteristics and some aspects of implementation]. Almanakh prava, 3, 275-279. [in Ukrainian].
15. Chervonyuk, V. I. (2004). Kontitutsionnoe pravo Rossii [Constitutional law of Russia]. Moscow: Termika, Infra-M. [in Russian].

16. Ekimov, A. I. (1980). Spravedlivost i sotsialisticheskoe pravo [Justice and socialist law]. Leningrad: Izd-vo Leningr. un-ta. [in Russian].

17. Yavich, L. S. (1976). Obshchaya teoriya prava. [General theory of law]. Leningrad: Izd-vo Leningrad. un-ta. [in Russian].

\title{
ПОНЯТТЯ ТА ЗМІСТ КОНСТИТУЦІЙНОГО ПРИНЦИПУ СПРАВЕДЛИВОСТІ
}

\author{
Наталія Шелевер, \\ доцентка кафедри адміністративного, фінансового \\ та інформаційного права Ужгородського національного університету, \\ кандидатка юридичних наук,доцентка \\ /orcid.org/0000-0003-3641-4910 \\ Researcher ID: AAI-9623-2021 \\ (https://publons.com/researcher/4326660/nataliya-shelever/) \\ nataliya.shelever@uzhnu.edu.ua
}

\section{Анотація}

Мета статті полягає у дослідженні поняття та змісту конституційного принципу справедливості, його впливу на конституційно-правові відносини, виявленні проблем, які виникли при реалізації цього принципу під час карантинних обмежень внаслідок пандемії COVID-19.

Дану мету було досягнуто завдяки застосуванню такого методу як аналіз, порівняльно-правового та формально-юридичного методу.

При дослідженні встановлено, що принцип справедливості хоча і не закріплений у Основному Законі України, проте він пронизує як Конституцію України, так і процесуальні кодекси. Проблемним питанням $є$ те, що відсутнє законодавче визначення поняття «справедливість». Проаналізовано практику Конституційного Суду України щодо застосування принципу справедливості у його рішеннях. Обгрунтовано, що справедливість є поняттям значно ширшим, ніж право та є критерієм легітимації державної влади.

Досліджено проблеми реалізації конституційного принципу справедливості. При цьому виявлено, що принципи права, які закріплені в Конституції України та діючому законодавстві України, не реалізовуються належним чином в нашій державі. Причиною цього є менталітет українців, який характеризується низькою правовою та політичною культурою, порушенням вимог закону, недовірою до влади, знеціненням моральних та духовних цінностей. Зі сторони чиновників - зловживанням своїм посадовим становищем.

Обгрунтовано, що справедливість вимагає однакового застосування закону для всіх. Проте у кожної людини є своє розуміння і бачення справедливості. Це призвело до проблем під час пандемії коронавірусної інфекції. Виявлено такі порушення як порушення конституційного права на освіту, а саме дистанційне навчання призводить до порушення принци- 
пів справедливості та рівності. Обмеження для малого та середнього бізнесу під час пандемії COVID-19 поставило у дискримінаційне становище підприємців у порівнянні з великим бізнесом.

У результаті дослідження зроблено висновок про те, що справедливість є правовою цінністю та основоположним принципом права, який пронизує як Конституцію України, так і чинне законодавство. Реалізація справедливості може бути здійснена лише шляхом дотримання закону. В Україні доволі складно реалізувати цей принцип, бо і закони часто є несправедливими. Під час карантинних обмежень виявлено порушення конституційних прав людини. Необхідним кроком для ефективної реалізації принципу справедливості має стати подолання корупції та підвищення правової культури та правової свідомості українців.

Key words: справедливість, Конституційний Суд України, право, правова цінність, принцип права, пандемія COVID-19, Конституція України. 